\title{
Internal Iliac Artery Branch
}

National Cancer Institute

\section{Source}

National Cancer Institute. Internal lliac Artery Branch. NCI Thesaurus. Code C32846.

Any artery arising from the internal iliac artery. 